\title{
A Vertical Exposure of the 1999 Surface Rupture of the Chelungpu Fault at Wufeng, Western Taiwan: Structural and Paleoseismic Implications for an Active Thrust Fault
}

\author{
by Jian-Cheng Lee, Yue-Gau Chen, Kerry Sieh, Karl Mueller, Wen-Shan Chen, \\ Hao-Tsu Chu, Yu-Chang Chan, Charles Rubin, and Robert Yeats
}

\begin{abstract}
We mapped and analyzed two vertical exposures-exposed on the walls of a 3- to 5-m-deep, 70-m-long excavation and a smaller 3-m-deep, 10-m-long excavation-across the 1999 rupture of the Chelungpu fault. The primary exposure revealed a broad anticlinal fold with a 2.5 -m-high west-facing principal thrust scarp contained in fluvial cobbly gravel beds and overlying fine-grained overbank deposits. Sequential restoration of the principal rupture requires initial failure on the basal, east-dipping thrust plane, followed by wedge thrusting and pop-up of an overlying symmetrical anticline between two opposing secondary thrust faults. Net vertical offset is about $2.2 \mathrm{~m}$ across the principal fault zone. From line-length changes, we estimate about $3.3 \mathrm{~m}$ of horizontal shortening normal to fault strike. The ratio of these values yields a total slip of $4.0 \mathrm{~m}$ and an estimate of about $34^{\circ}$ for the dip of the fault plane below the excavation. This value is nearly the same as the $35^{\circ}$ average dip of the fault plane from the surface to the hypocenter. Restoration of the exposed gravelly strata and adjacent overbank sediments deposited prior to the 1999 event around the principal rupture suggests the possible existence of a prior event. A buried 30-m-wide anticlinal warp beneath the uplifted crest of the 1999 event is associated with three buried reverse faults that we interpret as evidence for an earlier episode of folding and faulting in the site. The prior event is also recorded in the smaller excavation, which is located $40 \mathrm{~m}$ south and is oriented parallel to the larger excavation. Radiocarbon dating of samples within the exposed section did not place tight constraints on the date of the previous event. Available data are interpreted as indicating that the previous event occurred before the deposition of the less than $200{ }^{14} \mathrm{C}$ yr B.P. overbank sands and after the deposition of the much older fluvial gravels. We interpret the previous event as the penultimate event relative to the 1999 ChiChi earthquake. We estimated the long-term slip rate of the Chelungpu fault to be $10-15 \mathrm{~mm} / \mathrm{yr}$ during the last $1 \mathrm{Ma}$, based on previously published retrodeformable cross sections. This rate is, however, significantly higher than geodetic rates of shortening across the Chelungpu thrust where two pairs of permanent Global Positioning System stations suggest $7-10 \mathrm{~mm} / \mathrm{yr}$ of shortening across the fault. Given the $4 \mathrm{~m}$ of average slip, the long-term slip rate yields an interseismic interval of between 267 and $400 \mathrm{yr}$ for the Chelungpu fault.
\end{abstract}

\section{Introduction}

Historic surface ruptures of thrust faults are much less common than those that occured along normal and strikeslip faults, in the last century. The long surface rupture of the $1999 M_{\mathrm{W}}$ 7.6 Chi-Chi earthquake in central western Taiwan (Central Geological Survey [CGS], 1999a,b; Institute of Earth Sciences [IES], 1999; Ma et al., 1999; Kao and Chen,
2000) thus provides an unusual opportunity to characterize the behavior of an active thrust fault. Surface ruptures produced by the Chi-Chi earthquake typically consisted of a single major scarp with or without multiple minor scarps that collectively exhibited vertical throws as high as 5-8 m (CGS, 1999b; Chen et al., 2001). In this study, an excavation across 
the scarp allowed us to examine the structures associated with the scarp in the shallow subsurface and to broadly constrain the timing of a previous event.

The Chi-Chi earthquake resulted principally from failure of the Chelungpu fault (CGS, 1999b; Ma et al., 1999; Chen et al., 2001), a major range-front thrust in the fold and thrust belt of western Taiwan (Fig. 1). The hypocenter of the mainshock was located at a depth of 5 to $10 \mathrm{~km}$, about $10 \mathrm{~km}$ east of the surface trace of the thrust fault (Chung and Shin, 1999; Ma et al., 1999; Kao and Chen, 2000), broadly consistent with earlier (Suppe, 1987) and recent (Angelier et al., 2000; Mouthereau, 2000) determinations of the shape of the fault from construction of retro deformable cross-sections (Fig. 1).

During the earthquake, the entire $90-\mathrm{km}$ length of the $\mathrm{N}-\mathrm{S}-$ trending Chelungpu thrust ruptured (Fig. 1). The northern end of the surface rupture is defined by a $15-\mathrm{km}-$ long NE-SW to E-W-trending array of short anticlines and associated thrust faults, which were accompanied by substantial surface deformation. The southern end of the Chelungpu fault is defined by a 5- to $10-\mathrm{km}$-long right-lateral strike-slip tear fault trending NNE to NE that also ruptured in the earthquake. Coseismic deformation from the earthquake is defined by variations in magnitudes of slip as recovered from seismic inversions (Kikuchi et al., 2000; Ma et al., 2000) and from Global Positioning System (GPS) measurements (CGS, 1999b; IES, 1999; Yu et al., 2001), which show a gradual increase of slip from about $2 \mathrm{~m}$ in the south to about $8 \mathrm{~m}$ in the north - values similar to mapped surface displacements (CGS, 1999b; Chen et al., 2001; Lee et al., 2001).

Most of the surface ruptures of the Chelungpu fault in 1999 closely followed old scarps along the range front. The range front represents a principal morphological and geological boundary in western Taiwan between Miocene-Pliocene rocks of the rugged foothills and Quaternary alluvial deposits of basin, tableland, and coastal plain. Total geological dip slip across the Chelungpu fault has been about 10$15 \mathrm{~km}$, probably in the past 1 million yr, according to the balanced geological cross sections (Suppe, 1987; Angelier et al., 2000; Mouthereau, 2000; Mouthereau et al., 2001).

Although older pre-existing scarps exist along many of the 1999 rupture, deposition of alluvial sediments and erosion have partly obscured or removed the geomorphic trace of previous ruptures in some locations. As a consequence, despite the morphological evidence for prior ruptures, the precise location of the surface trace of the fault and the most recent activity along it were poorly defined before the earthquake. The surface breaks of the 1999 Chi-Chi earthquake thus provided an unusual opportunity to map the active surface trace of the Chelungpu thrust (CGS, 1999a), to relate it to deformation in the shallow subsurface, and to define the record of earlier ruptures as defined by relict scarps and scarp-derived colluvium in trench excavations (e.g., Chen $e t$ al., 2001).

We therefore sought to determine how surficial features along the 1999 surface rupture were related to structures in the shallow subsurface. We also sought to determine when the older scarps had formed, the recurrence interval between the 1999 and earlier events, and whether previous events were similar to the 1999 rupture.

\section{Excavation}

While examining the 1999 rupture in March 2000 near Wufeng (Figs. 1, 2), we discovered a recent excavation across the newly formed fault scarp. We employed a local track-hoe operator to deepen and lengthen the exposure into a 70-m long, 3- to 5-m-deep excavation (T1) along the northern edge of an open field previously used for agricultural purposes (Fig. 3). An additional small excavation about 10 $\mathrm{m}$ long and $3 \mathrm{~m}$ deep (T2) was opened $40 \mathrm{~m}$ south of the main excavation in a subsequent investigation. The resulting exposures were then cleaned by hand with small scrapers and brushes. We surveyed and mapped readily identified stratigraphic contacts in the principal exposure and collected charcoal for radiocarbon analysis. Mapping control was provided with a horizontal level marked at 1-m intervals in the primary excavation.

\section{Geological Setting of the Site}

Surface ruptures at Wufeng site were located in Holocene or late Quaternary alluvial deposits on a floodplain, 100 to $200 \mathrm{~m}$ west of the base of the mountain front (Fig. 2). Pliocene shallow-marine strata are exposed to the east in the foothills belt where they are about $2000 \mathrm{~m}$ thick. At the excavation site, Pliocene strata lie about 8 to $10 \mathrm{~m}$ below the surface of the hanging-wall block, based on nearby exposures. On the footwall block, the thickness of Pliocene rocks beneath Quaternary fluvial strata is not well constrained but is probably about $2 \mathrm{~km}$, based on data from a nearby seismic reflection profile (Chou, 1971).

The surface rupture at the Wufeng site was associated with a linear ridge, which is bounded to the west by a continuous 2.5-m-high west-facing scarp (main scarp) and to the east by a discontinuous east-facing scarp less than $1 \mathrm{~m}$ high (Figs. 2, 3). Collapse and severe damage of buildings located across the main scarp and ridge was common. The surface trace of the scarp was characterized by high sinuosity, typical of other historic thrust fault ruptures, such as the 1980 Algerian (Philip and Meghraoui, 1983) and the 1987 Spitak (Philip et al., 1992) events.

\section{Stratigraphy}

The exposures revealed fluvial gravels and fluvial sand capped by a soil profile (Fig. 4). We define the stratigraphy of the exposure into three types of deposits, from bottom to top: (1) gravel, (2) a sequence of upward-fining sand, and (3) human-cultivated soil. Further subdivision of the units based on sedimentary facies was developed on the exposed 

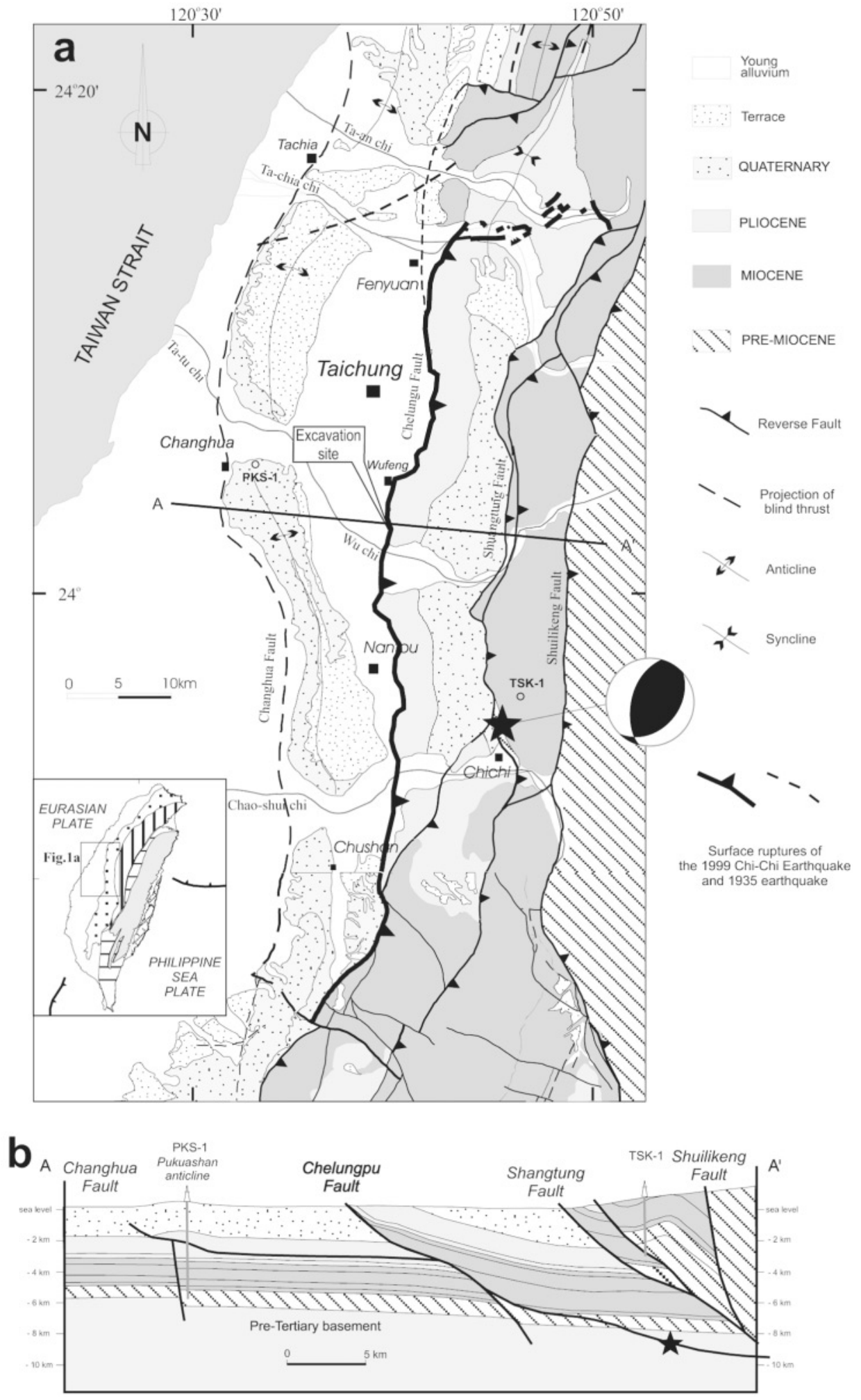

Figure 1. General geologic map (after Chinese Petroleum Corporation, 1974, 1982) and corresponding geologic cross section (after Angelier et al., 2000) of the central western Taiwan. Shortening in the central western Taiwan is accommodated by a series of west-vergent thrusts. The Chi-Chi earthquake resulted principally from the failure of a major thrust, the Chelungpu fault, in this fold and thrust belt. 


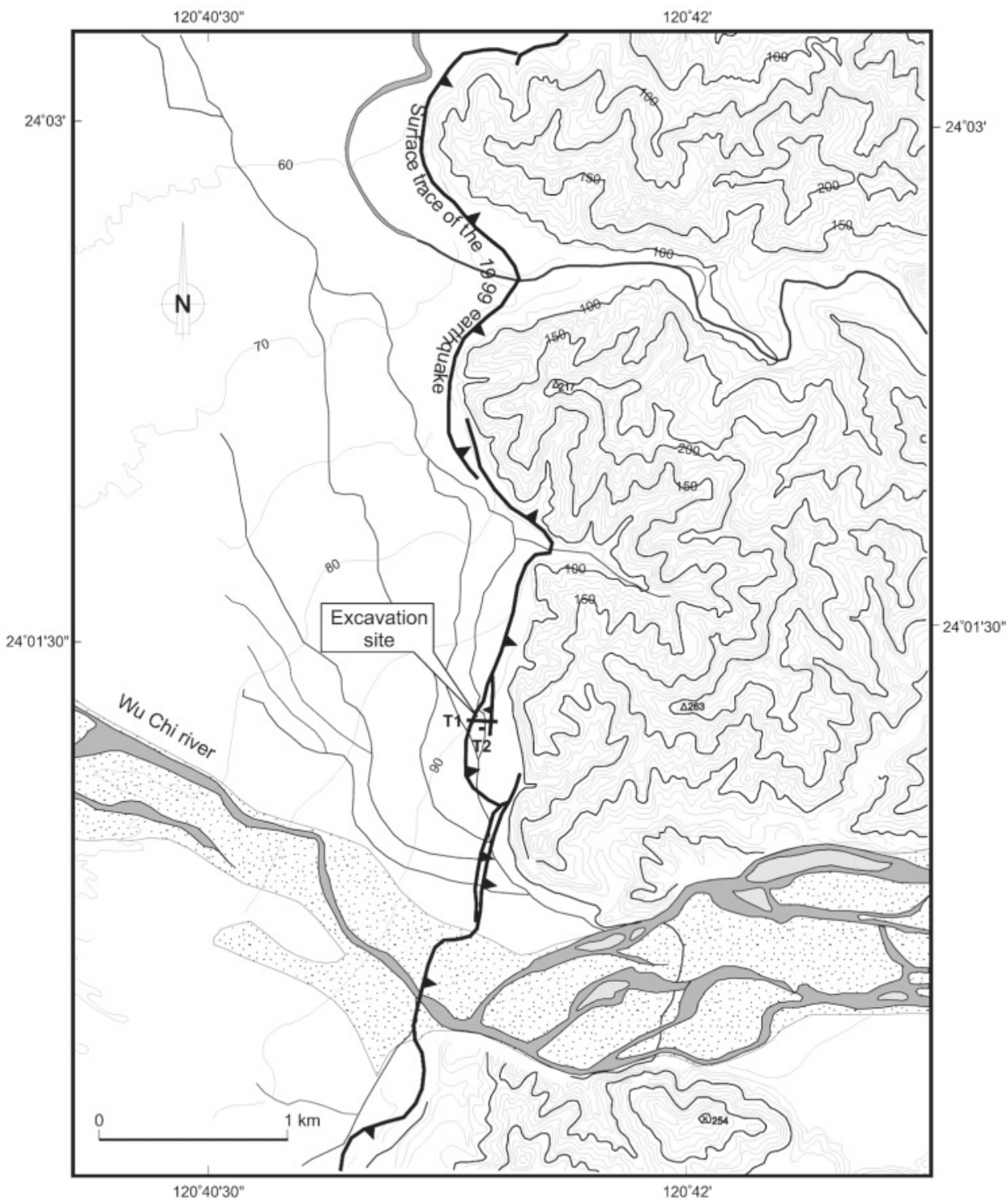

Figure 2. Topographic map of the area of the excavation site. Contour interval is $10 \mathrm{~m}$. The site is located near the $\mathrm{Wu}$ Chi river. T1 is the primary $70-\mathrm{m}$-long excavation. $\mathrm{T} 2$ is the 10-m-long excavation. Topography indicated by the contour lines shows an alluvial fan whose head lies at of the Wu Chi river, which currently flows across the northern portion of the fan.

walls of the excavations, which are illustrated in Figures 5 and 6.

The lowest unit, unit 10 , is comprised of cobbly gravel deposited in a fluvial environment. The gravel unit is 1.5 and 2-3 $\mathrm{m}$ thick on the footwall block and the hanging-wall block, respectively (Fig. 5). The gravels are framework supported and contain well-rounded, cobble-sized clasts. Based on grain size and the location of the trench excavation adjacent to the mouth of a small river canyon, we interpret the gravels as being deposited in a high-energy fluvial environment. Deposition of fluvial sediment has not occurred during the last $30 \mathrm{yr}$ at the site, due to construction of an artificial levee located $1 \mathrm{~km}$ to the south.
Above the cobbly gravel deposits, different sedimentary sequences exist across the main fault zone of the 1999 rupture. On the hanging wall, overlying sands consist of several fining-upward, nearly tabular beds of fine- to coarse-grained sand with minor interbeds of mud (units 2, 3, 4, 5, and 6) that are collectively about $2 \mathrm{~m}$ thick. The sandy beds are interpreted to be overbank deposits. Further subdivision of the sandy overbank deposits suggests the lower part of the unit is comprised of four beds of yellowish coarse-grained sand that fines upward into brownish mud (units 3, 4, 5, and $6)$. The upper $30 \mathrm{~cm}$ of the $2-\mathrm{m}$ thick sand sequence is represented by yellowish fine- to medium-grained sand. Sparse plant fragments and disseminated organic matter in the mud 


\section{Principal excavation along this wall}
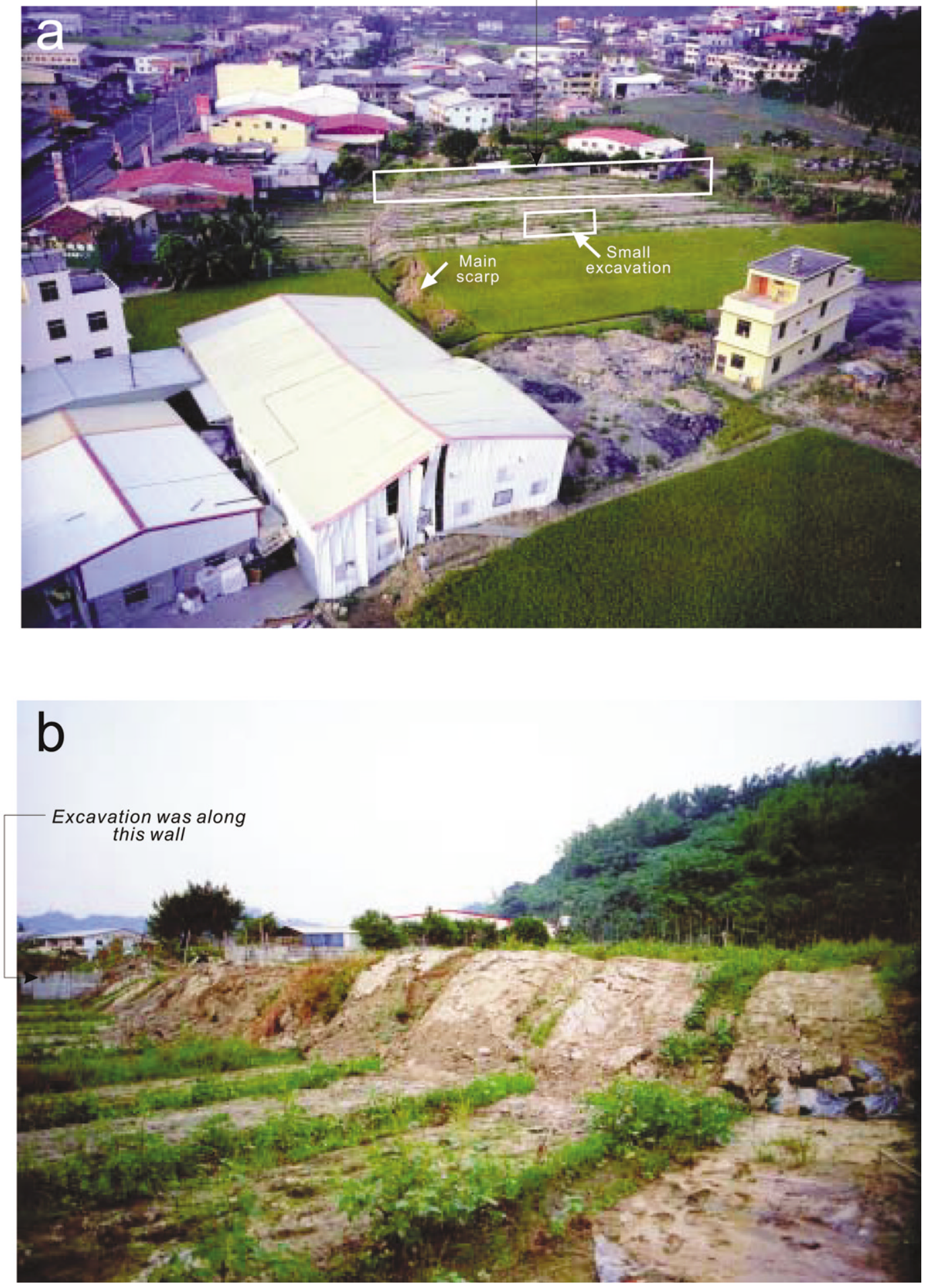

Figure 3. Photographs of the surface ruptures at the Wufeng excavation site. (a) A broad anticline with a continuous west-facing thrust scarp to the west and a subtle eastfacing scarp to the east. The principal exposure (T1) was excavated along the edge of the paddy field, as indicated by the white rectangle. Note the location of the west-facing scarp beneath the building in the foreground. (b) The main, 2- to 3-m-high west-facing thrust scarp and pop-up anticline in paddy field. 


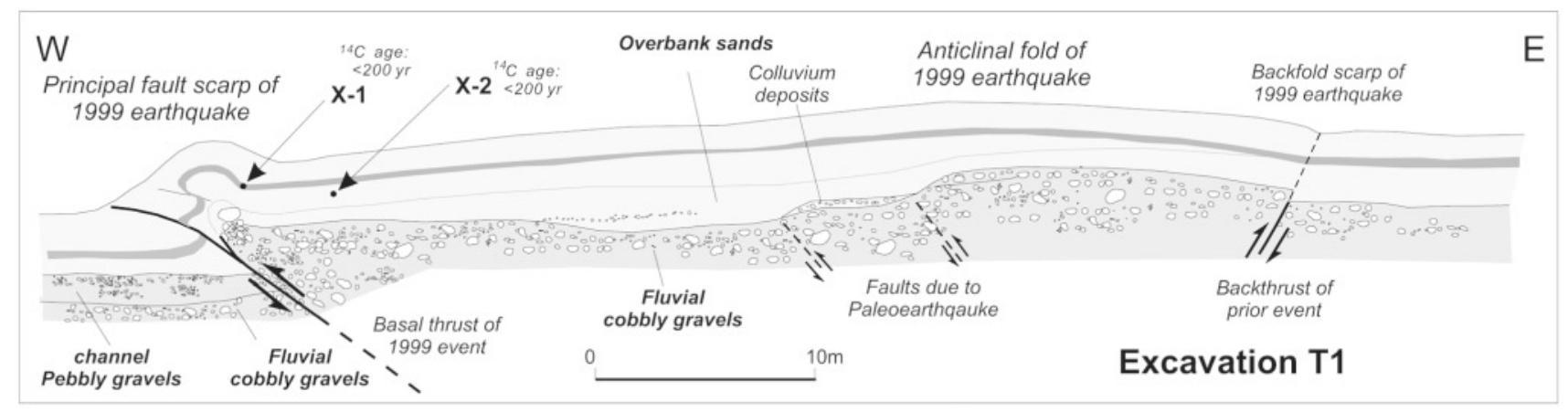

Figure 4. Simplified structures exposed in the 70-m-long profile. Deformation was accommodated by a $60-\mathrm{m}$-wide broad anticlinal fold with a major west-facing thrust scarp to the west and a minor east-facing backthrust (or backfold) scarp to the east. A buried anticlinal warp beneath the broad anticline crest of the 1999 event is associated with three buried thrust faults, suggestive of a prior event occur after deposition of the basal gravels.

interbeds are interpreted as incipient soil, a horizon between the overbank sands. Correlative strata exposed on the footwall of the fault include $80 \mathrm{~cm}$ of pebbly gravel (unit 8 ) overlain by overbank sands (units 2 and 3) that are deposited above the cobbly gravel deposits. We interpret the pebbly gravel to be deposited in a fluvial channel environment under relatively lower energy conditions than the underlying cobbly gravel deposits.

The uppermost bed is dark gray silty clay (unit 1) that is uniformly $40-50 \mathrm{~cm}$ thick. The presence of modern cultural debris in the clay suggests it is a cultivated paddy soil. No evidence, based on oral interviews with local farmers, exists for pre-existing topography across the paddy field prior to the 1999 earthquake. Given the origin of the paddy clay as an agricultural soil and the lack of pre-existing relief at the site, we argue the base of the unit was horizontal prior to 1999 and thus provides a horizontal datum, which we discuss and exploit in a later section on restoring deformation produced in the 1999 event.

\section{Age of Deposits}

Several samples, including wood, plant roots, and charcoal, were collected in different deposits for the radiocarbon dating. Two of the dates (samples X-2 and Y) were carried out at the Radiocarbon Dating Lab of University of Waikato, New Zealand, using accelerator mass spectrometry (AMS). Sample X-1 was dated by AMS at Lawrence Livermore National Laboratory (LLNL). Sample Z was dated at the Radiocarbon Dating Laboratory of National Taiwan University using conventional dating techniques.

Radiocarbon ages of $32.5 \pm 0.3 \mathrm{ka}$ and $42.8 \pm 1.1 \mathrm{ka}$ from two samples ( $\mathrm{Y}$ and $\mathrm{Z}$ ) of driftwood in the gravel deposits of the small additional excavation suggest that at least the lowest exposed gravels are late Pleistocene in age (Fig. 6 ). We question the reliability of this age assignment, however. If the gravels are as old as these dates, they should be marked by considerable oxidation and weathering, at least in comparison with other well-dated 40-ka gravel deposits elsewhere in western Taiwan. That does not appear to be the case, suggesting the 30 - to $40-\mathrm{ka}$ age is problematic. Alternatively, the 30- to 40-ka age represents the age of the lowest exposed gravels. However, a significant depositional hiatus likely exists between the lower and upper gravels. We thus suspect in either way that the upper gravels are considerably younger than the assigned radiocarbon ages.

Two samples collected within the brownish mud layers of the overbank sand deposits included a carbonized plant rootlet within the brownish mud layer of unit 3 (X-1 in Fig. 4) and pieces of rootlet about $10 \mathrm{~cm}$ also below in the brown mud layer of unit 4 (X-2 in Fig. 4). Both samples yielded a ${ }^{14} \mathrm{C}$ age of modern age, that is, less than $200 \mathrm{yr}$. We thus interpret this age to represent the approximate age of the overbank sand deposits.

\section{Deformation at the Main Rupture}

\section{General Features of the Surface Rupture}

At the Wufeng site, the principal fault zone appeared as a 2.5-m-high west-facing scarp and a lesser east-facing scarp (Figs. 3-5). The excavation is interpreted to suggest that the low-amplitude anticline between the two scarps was produced by slip on an east-dipping main thrust fault. Furthermore, Figure 4 shows that the principal fault zone bounds the western margin of this subtle 50-m-wide anticline. The amplitude of the broad fold is about $2.5 \mathrm{~m}$, and its crest is about $30 \mathrm{~m}$ east of the principal rupture. We interpret the anticline as forming in the 1999 event because all of the sediments are warped, and the youngest deposits do not thin over the crest of the fold. Two east-dipping buried thrust faults within the gravel layers are apparent beneath the anticline in the middle portion. 

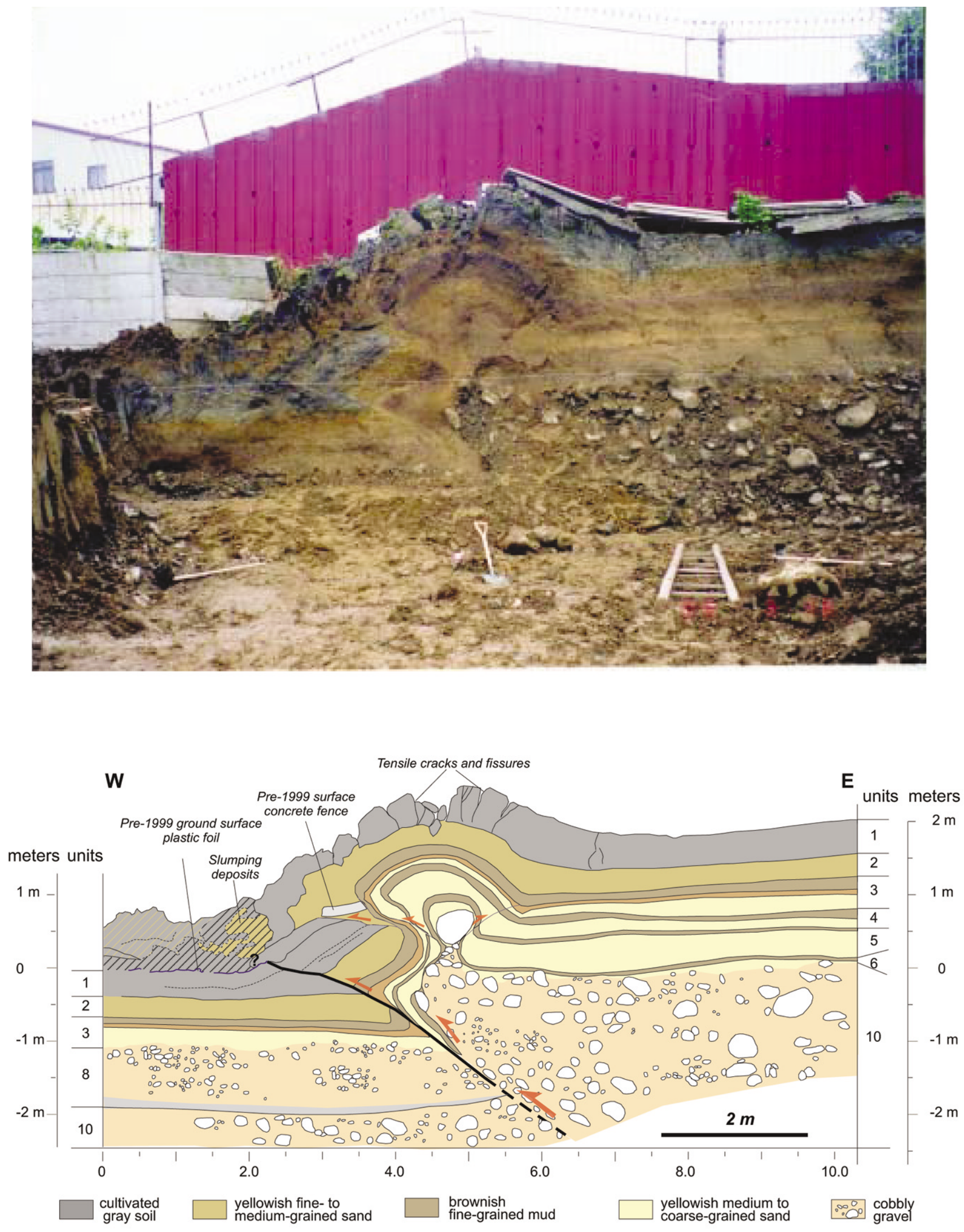

Figure 5. Excavated vertical exposure on the principal rupture illustrated by (a) a photograph and (b) an interpreted cross section. The deformation of the principal thrust scarp is characterized by a basal thrust and a pop-up anticlinal fold with two opposing thrusts. 


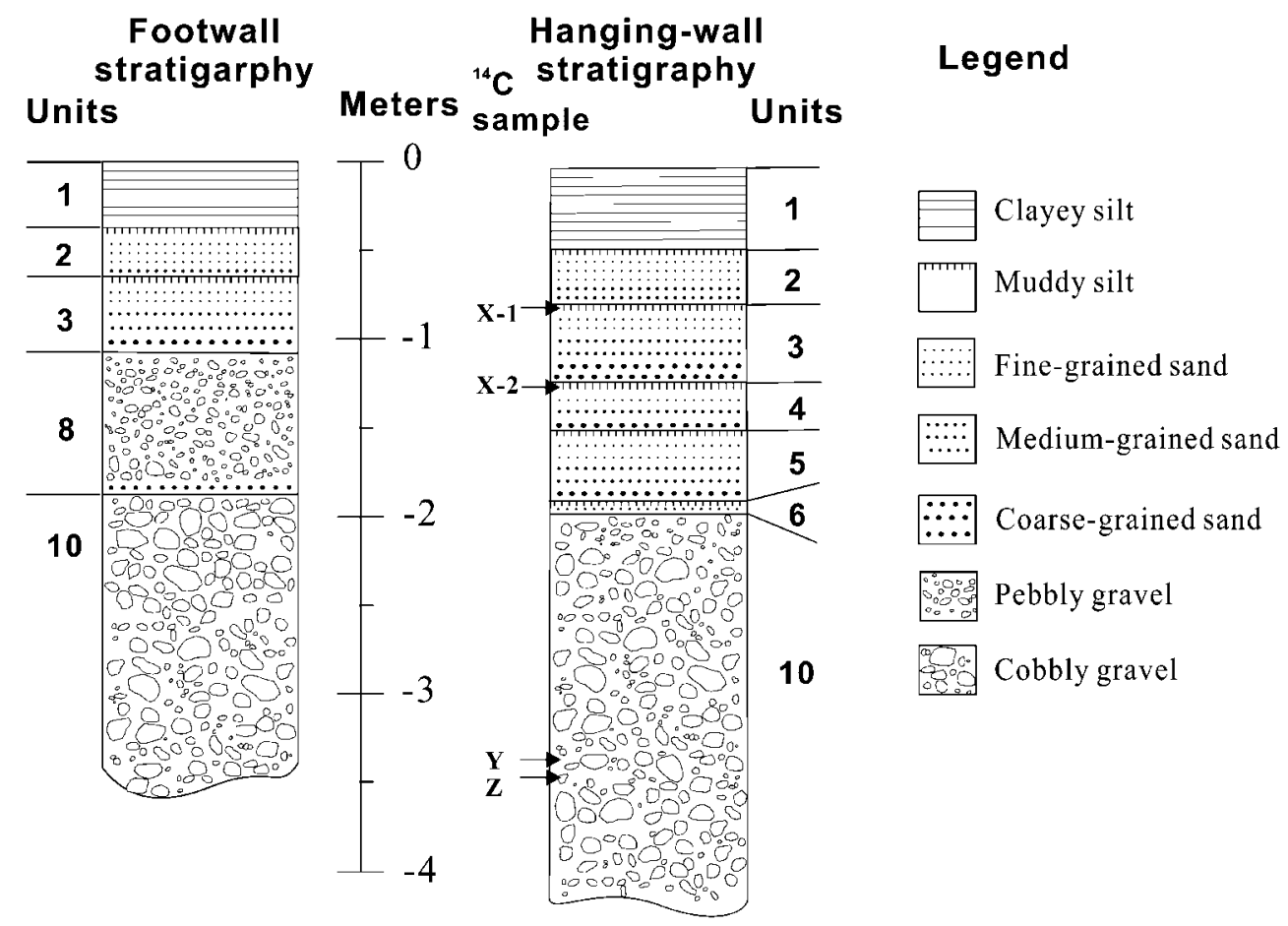

Figure 6. Generalized stratigraphic column of sedimentary deposits in the principal rupture on the primary excavation T1. Units are numbered for discussion in text. Strata consist of fining upward sequences of overbank sands and fluvial gravels. Vertical hatch marks on muddy silt show an incipient soil profile. Note difference in sequences on the footwall versus the hanging wall. The stratigraphic position of the radiocarbon samples is shown as $\mathrm{X}-1, \mathrm{X}-2, \mathrm{Y}$, and $\mathrm{Z}$.

\section{Details of the Principal Rupture}

The principal, east-dipping thrust fault dips $30^{\circ}-35^{\circ}$ at the base of the exposure but lies nearly flat near the top of the excavation (Fig. 5). Offset along the principal thrust fault in the excavation is about $1-2 \mathrm{~m}$ in the middle of the exposure but diminishes upward. Figure $5 b$ shows that the uppermost end of the basal thrust is coincident with a sheet of plastic used to cover the agricultural field before the earthquake. This suggests the fault ruptured through to the ground surface at the excavation site.

The anticlinal fold above the basal thrust is bounded by two oppositely dipping thrust faults (Fig. 5), which root and merge at the base of a large boulder in the core of the fold. Each fault is associated with significant warping of hangingwall and footwall blocks that verges in the same outward sense as fault slip. The magnitude of dip slip and folding decreases updip along the eastern thrust fault. The folded limbs flanking this fault are thinned and overturned at the base of the overbank sands, whereas they are continuous and form an open fold beneath the upper soil. The fold is wider and less tightly appressed at the ground surface. The amplitude of the fold is about $65 \mathrm{~cm}$. Dip slip along the westernbounding fault is greatest where it breaks the gray soil and the underlying fine to medium sand. The thrust fault breaches the prerupture ground surface and translates the gray soil and fine to medium sand of the hanging-wall block about $1 \mathrm{~m}$ onto the gray paddy soil on the footwall block.

Across the crest of the fold and the upper half of both fold limbs, the uppermost $50 \mathrm{~cm}$ of paddy soil exhibit open, tensile fractures (Fig. 5). These indicate that extension occurred across the crest of the fold during faulting. Furthermore, from the crest and west limb of the anticline, the gray soil (unit 1) and underlying fine to medium sand (unit 2) have slumped downslope. These units are thinner on the upper half of the scarp and thicker on the lower half. Sedimentary structures at the base of the scarp also clearly indicate slumping from the face of the scarp.

\section{Development of the Principal Rupture}

The relationship of faulting and folding to the deformed strata allowed us to partially reconstruct the history of scarp formation (Fig. 7), although this probably occurred in less than a few seconds, according to accounts of local people and inversions of seismograms (Kikuchi et al., 2000; Ma et al., 2000). We are able to infer a multistage process of faulting, folding, and scarp development.

We use the amount of dip-slip displacement measured across each fault and the stratigraphic cutoff angles between offset bedding and the faults to infer the development of structures exposed in the excavation beneath and within the 


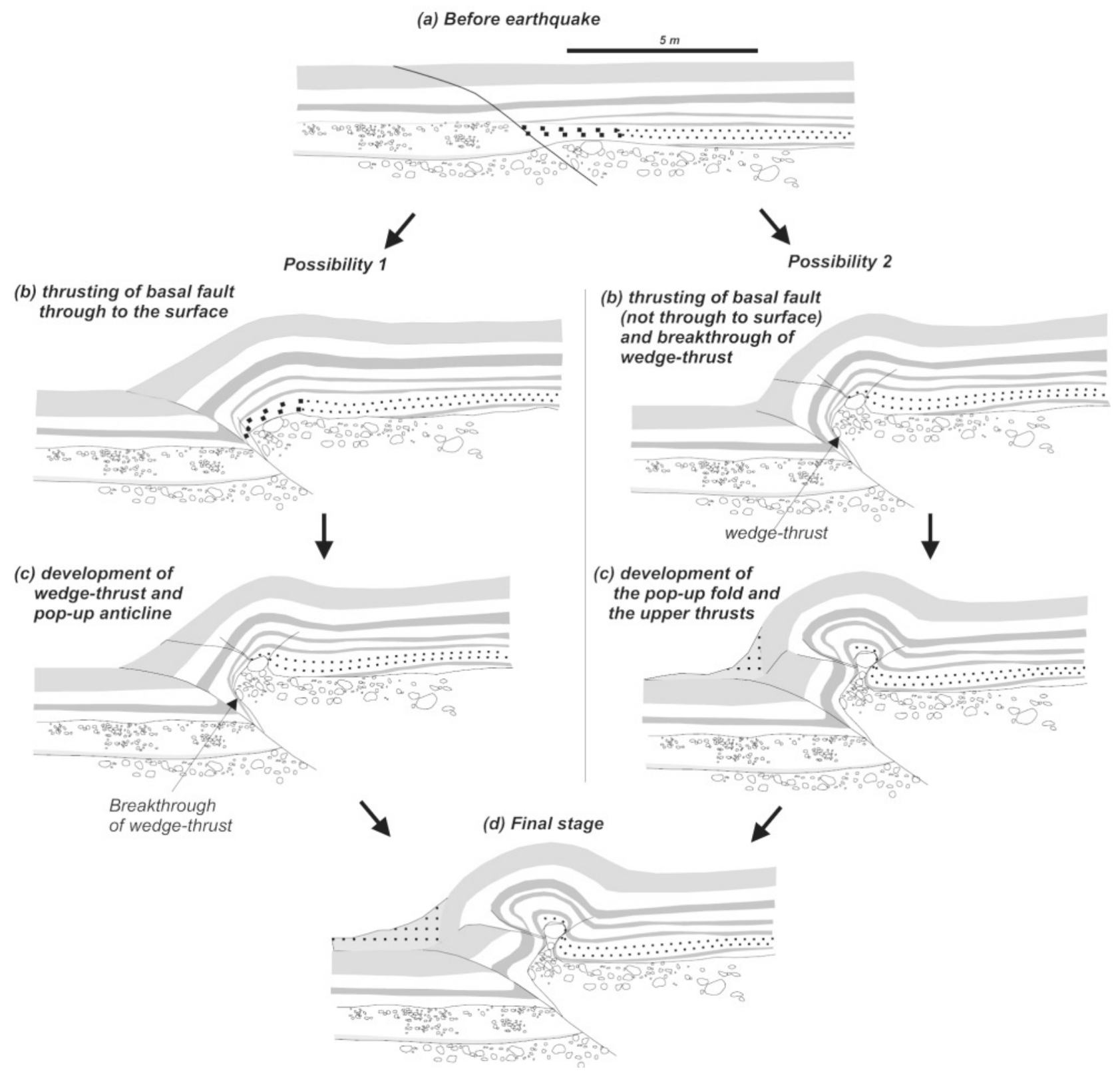

Figure 7. Hypothetical evolution of the main thrust scarp produced by the 1999 Chi Chi earthquake. Two scenarios are shown. Before the earthquake in 1999, an ancient scarp likely existed on the top level of the gravel deposits (a). In the first scenario, the basal fault ruptured through to the ground surface (b) followed by wedge thrusting and development of the popup anticlinal fold (c). In the second scenario, the basal fault did not initially rupture through to the surface (b) but formed simultaneously with the wedge thrust and the pop-up fold bounded by the two opposing thrusts $(b, c)$ In this scenario, only later did the basal fault finally rupture across the surface $(\mathrm{d})$.

pop-up anticline. The following observations form the basis for our structural interpretation. All of the three discrete thrust faults exposed in the excavation exhibit less than $\sim 130 \mathrm{~cm}$ of dip-slip separation, thus all collectively contribute to the much greater amount of shortening recorded in the structure. The basal thrust dips between $12^{\circ}$ and $35^{\circ}$ and flattens toward the ground surface. Strata contained in the footwall of the basal thrust are largely undeformed ex- cept for minor drag contained within a 10 - to 20 -cm-thick sheet beneath the discrete fault surface. A thrust exposed above the basal slip surface offsets the overturned western limb of the pop-up anticline and exhibits between 80 and $110 \mathrm{~cm}$ of dip-slip displacement. It cuts upward through the clast-supported gravel at a very steep angle $\left(\sim 90^{\circ}\right)$ and at an angle of $40^{\circ}$ through the overlying paddy clay. Both the faults discussed previously verge toward the west. The third 
fault observed in the excavation thrust zone dips $36^{\circ}$ west, verges east, and is exposed at the base of the east-dipping limb of the pop-up anticline. Apparent stratigraphic separation across the east-verging thrust ranges from essentially zero, where it is interpreted to lie parallel to bedding at the top of the gravel layer, to less than $20 \mathrm{~cm}$ at the base of the east-dipping limb of the pop-up anticline.

Based on the geometric relationships between fault and fold geometry and stratigraphic cutoffs, we interpret the surface rupture and the pop-up anticline to have developed in the following sequence (Fig. 7). Initial rupture along the $35^{\circ}$ east-dipping Chelungpu thrust occurred as the primary thrust extended up from the hypocenter. As the rupture approached the surface, it developed into a more complex structure that included (1) a basal thrust that ruptured to the surface, (2) a wedge-thrust structure whose top was coincident with the top of the gravel bed, and (3) a buckle fold and two secondary thrusts that verge outward from the core of the pop-up anticline. Stratigraphic cutoff angles and the location of the outwardly verging pair of thrusts suggest they formed coincident with growth of the anticline, in a manner similar to fault propagation folds. The east-dipping thrust propagated to the surface, while the tip of the west-dipping thrust was arrested 1-1.5 $\mathrm{m}$ beneath the surface. The wedge-thrust structure experienced breakthrough of the basal thrust, although the timing of the breakthrough relative to uplift of the anticline is uncertain.

Quantitative Analysis of Deformation across the Principal Fault Zone

We estimated the amount of horizontal shortening and vertical uplift across the fault zone in the plane of the exposure. From this we also estimated the dip of the fault plane and total slip in the plane of the exposure. We estimated the magnitude of horizontal deformation across the major fault zone from line-length measurements along five of the sedimentary contacts. Figure 8 shows measurements of line lengths for each of these horizons. The line lengths for each horizon were measured along distinct contacts that were separated by faults and tensile fissures. The values represent the lengths (in m) of each segment. We chose four of these five horizons for the line-length estimate because the uppermost horizon (red line in Fig. 8) is incomplete and difficult to measure.

We add the measurements for each section of stratal contact and compare the summed length to the prefaulting length of the profile, $10.2 \mathrm{~m}$. The difference in line length is a measure of the amount of horizontal shortening parallel to the exposure. The four values of horizontal shortening range from 3.2 to $3.8 \mathrm{~m}$ (Table 1). This yields an average value for horizontal shortening of $3.3 \pm 0.3 \mathrm{~m}$. To determine vertical offset across the 1999 rupture, we calculated the difference in elevation of the beds between points east and west of the fault zone and pop-up anticline. These values range from 2.1 to $2.3 \mathrm{~m}$ (Table 1), with an average of $2.2 \pm 0.1 \mathrm{~m}$.
Based on the values we determined for horizontal and vertical displacement, the total slip and the dip of the thrust fault beneath the excavation can be determined. Given that the tangent of the fault dip angle is equal to the vertical offset divided by the horizontal offset, we obtain a dip angle of $34 \pm 3^{\circ}$. This is equivalent to the dip of the fault exposed in the excavation, which is about $35^{\circ}$. From the horizontal and vertical components, we likewise calculate that slip along the fault plane is $4.0 \pm 0.2 \mathrm{~m}$, in the plane of the exposure.

\section{Evidence for a Paleoearthquake}

In addition to the deformation clearly associated with the 1999 earthquake, we also found evidence for prior deformation (i.e., a seismic event) in the excavation profiles.

\section{Possible Prior Rupture along the Principal Rupture}

Dissimilarities in the strata on opposite sides across the principal rupture zone suggest evidence for a prior rupture at the excavation site. From the surface soil downward to the yellowish overbank sand deposits, beds in units 1,2, and 3 are nearly uniform in thickness and were deposited on both sides of the fault zone (Fig. 5). Below unit 3, however, only the cobble to boulder gravel of unit 10 is exposed on both sides of the fault zone. On the hanging wall, three finingupward sand and silt beds (units 4, 5, and 6) form a sequence 60 to $80 \mathrm{~cm}$ thick between unit 10 (the cobbly gravel bed) and unit 3 (the yellowish sand/silt). In contrast, these three sand beds are absent on the footwall. Instead, a 50- to 60$\mathrm{cm}$-thick layer of pebbly gravel (unit 8 ) occupies the same stratigraphic position. This gravel bed is clearly not correlative with the much coarser cobbly gravel bed on the hanging-wall block. Because the three sandy overbank beds on the hanging wall occupy the same stratigraphic position as the pebbly channel gravel on the footwall block, we argue that units 4,5 , and 6 are broadly contemporaneous with unit 8 .

The marked facies difference between the hanging-wall and the footwall blocks (i.e., the edge of a pre-existing river channel of unit 8 with associated overbank deposits of units 4,5 , and 6) suggests several possibilities (1) a lateral component of slip across the fault zone has juxtaposed coarse channel facies and fine overbank facies during prior events; (2) the two juxtaposed facies reflect the presence of a scarp prior to the 1999 event; or (3) a channel occupied the area along the scarp and then eroded the pre-existing scarp. There is little evidence for strike-slip displacement accommodated by the Chelungpu thrust based on its geomorphology and kinematic development or by numerous, carefully documented piercing points offset by the 1999 earthquake.

If the juxtaposition of strata at the excavation site, however, reflects the presence of a small fault scarp at the time of deposition of units $4-8$, then the facies contact would have been initially coincident with the fault. Restoration of the pre-1999 configuration of the beds indicates that the over- 
Length of undeformed profile: 13.3 meters
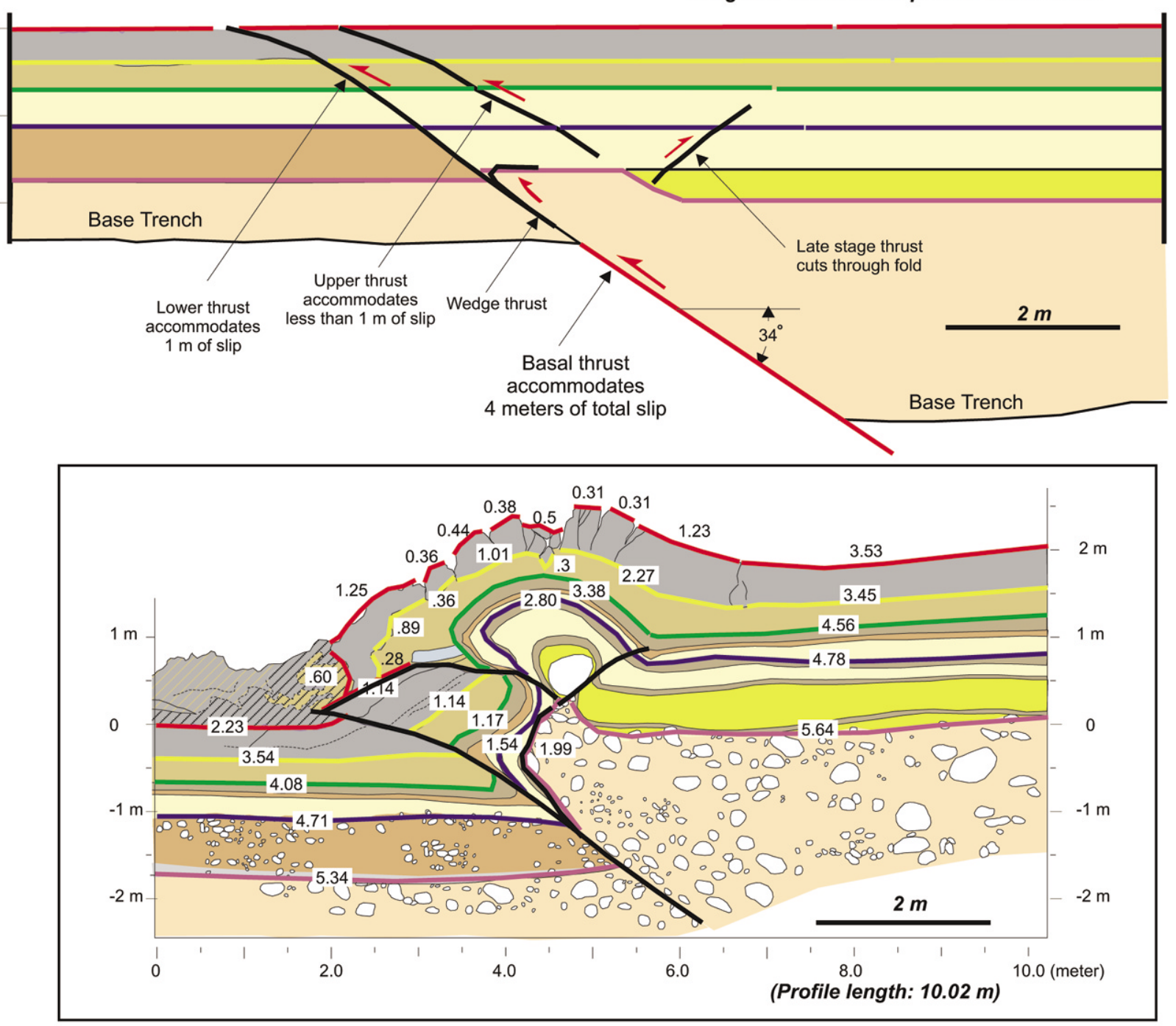

Figure 8. Restoration of the scarp and pop-up anticline based on measurement of line lengths. Five depositional contacts were measured. The upper figure is a stratigraphic separation diagram illustrating fault trajectories. The lower figure shows line lengths of each segment of the depositional contacts. The numbers on the lines of the depositional contacts indicate the lengths (in $\mathrm{m}$ ) for each segment, which are separated by tensile cracks and faults. The current length of the profile, $10.02 \mathrm{~m}$, is measured directly from the edges of cross section. Horizontal and vertical components of shortening are shown on Table 1.

bank section was located adjacent to the pebbly gravelly section with the contact between the two located less than $1 \mathrm{~m}$ east of the fault plane (Fig. 7a). We interpret this to suggest the following: (1) a channel filled with pebbly gravel beds eroded the lower part of the overbank deposits after the lower overbank section was deposited and before deposition of the upper, overlying overbank deposits, (2) the location of the channel was controlled by topography along a preexisting scarp, and (3) minor lateral migration of the river channel removed the scarp by erosion. Alternatively the location of the channel wall may be unrelated to a previous scarp, and its location adjacent to the recent surface rupture is a result of coincidence.
Evidence for Prior Deformation Elsewhere in the Excavations

Evidence for previous deformation is also apparent elsewhere at the site. An older anticlinal warp was exposed in the middle of the longer T1 excavation (Fig. 4) beneath the broad anticlinal crest of the 1999 event. The top of the bouldery gravel bed exhibits $2 \mathrm{~m}$ of structural relief between the crest of the anticline and the thrust ruptures at its end-a distance of $30 \mathrm{~m}$. The modern ground surface also exhibits anticlinal folding of about half that amount over the same distance. The warp in the top of the gravel is interpreted to be tectonic because it is bounded by reverse faults including two east-dipping faults on its west flank and a west-dipping 
fault on its east flank. Relief of about $1 \mathrm{~m}$ appears across the top of the gravel above each of these three fault traces (Fig. 9). Thinning of the overlying sands over the crest of the older anticline indicates that the feature was a topographic high after deposition of the gravel but before deposition of the sands. Furthermore, a 5- to $10-\mathrm{cm}$ thick bed of colluvium is deposited in a lens-shaped deposit at the base of the buried gravel scarps above the cobbly gravel. We interpret this colluvial deposit as additional evidence for a prior earthquake at the excavation site. These stratigraphic relationships constrain the prior event to have occurred after deposition of the coarse gravel but before deposition of the overbank sands.

A similar buried scarp in the gravels was exposed in the smaller T2 excavation, about $40 \mathrm{~m}$ south of the principal $\mathrm{T} 1$ excavation along the strike of the 1999 surface rupture (Fig. 10). The relationship between the scarp and deposition of the sandy facies at this site was obscured due to removal of the upper meter or two of sediment during earthquake recovery efforts prior to our work. Nonetheless, an eastdipping thrust fault and associated warp that deform gravels are exposed in the $\mathrm{T} 2$ excavation. This deformation is probably the along-strike continuation of the western flank of the anticline exposed in the longer excavation. Near the western side of the exposure (Fig. 10), the thrust fault offsets a gravel layer about $50 \mathrm{~cm}$ in a dip-slip sense. The offset gravel bed was later covered by sand. In the center of the outcrop, the gravel deposits are tilted toward the west. We interpret this to be due to distributed shear above a thrust fault.

In summary, both excavations reveal evidence for deformation that precedes the 1999 event. This episode of deformation occurred after the cobbly gravels were deposited and before deposition of the overbank sands.

\section{Discussion}

\section{Pop-Up-Deformation Structures across} Different Scales

We observed a characteristic pop-up structure at two different scales along the rupture of the 1999 Chi-Chi earthquake at Wufeng. At the excavation site, a small pop-up fold developed above the principal thrust scarp. A broader anticlinal structure is also present at the site, east of the pop-up. Elsewhere, even wider pop-ups formed during the earthquake (for example, a 2-km distance between principal thrust and backthrust or kink band developed on the hanging wall of the Chelungpu fault in the Tsaotun area, about $2 \mathrm{~km}$ south of the excavation site, and a 4-km-wide pop-up structure formed farther north, east of Fengyuan). These larger pop-up structures also appear in geodetic analyses of the coseismic deformation (CGS, 1999b; Yu et al., 2001). The 1999 rupture thus exhibited pop-up structures on a wide range of scales, from meters to kilometers.

Age, Size, and Frequency of Earthquakes

on the Chelungpu Fault

As discussed earlier, several lines of evidence exist for paleoseismic activity along the Chelungpu thrust prior to the
Table 1

Data Used in Calculating Shortening Across the Major Thrust Scarp

\begin{tabular}{lccccc}
\hline & $\begin{array}{c}\text { Measured } \\
\text { Length (m) }\end{array}$ & $\begin{array}{c}\text { Horizontal } \\
\text { Shortening (m) }\end{array}$ & $\begin{array}{c}\text { Vertical } \\
\text { Offset (m) }\end{array}$ & $\begin{array}{c}\text { Calculated } \\
\text { Total Slip (m) }\end{array}$ & $\begin{array}{c}\text { Derived Thrust } \\
\text { Dip Angle }\left({ }^{\circ}\right)\end{array}$ \\
\hline Yellow line & 13.24 & 3.22 & 2.22 & - & - \\
Green line & 13.19 & 3.17 & 2.14 & - & - \\
Blue line & 13.83 & 3.81 & 2.11 & - & - \\
Purple line & 12.97 & 2.95 & 2.28 & - & - \\
\hline Average & $13.3 \pm 0.3$ & $3.29 \pm 0.32$ & $2.19 \pm 0.07$ & $4.0 \pm 0.18$ & $33.6 \pm 3.1$ \\
\hline
\end{tabular}

Four horizons of depositional contacts were chosen for the analysis as indicated by colored lines in Figure 6. Line lengths were measured, summed, and compared with the width of the excavation. Horizontal shortening was obtained by the difference of the measured lengths and the current distances across the figure (10.02 $\mathrm{m}$ according to the measurement). Vertical offset was measured by far-field leveling of beds across the thrust and pop-up anticline. Total slip was obtained from the simple geometric triangular relationship between horizontal shortening and vertical offset. The dip of the thrust was calculated as the arctangent of the vertical offset divided by the horizontal shortening.

1999 rupture. Stratigraphy in the excavations shows that the prior event occurred after deposition of buried gravels and before the deposition of the overlying overbank sands. The upper $2 \mathrm{~m}$ of sand, silt, and mud deposits above the gravel beds have similar amounts of soil development and a similar degree of weathering except for the uppermost $30 \mathrm{~cm}$ of cultivated paddy soil. We thus argue there is no significant time gap between the sand, silt, and mud deposits. In fact, radiocarbon dating ages from two samples in the mud layers (units 3 and 4) both show they are modern in age (less than $200 \mathrm{yr}$ ). Unfortunately no further data are available within the colluvium deposits near the top of the gravels, and we are not confident that the ${ }^{14} \mathrm{C}$ age of $32-42$ ka B.P. within the lower gravel beds represents the true age of the deposit. Consequently, we are not able to obtain a tight age constraint from radiocarbon dates for the prior event observed in the excavations. However, the historical earthquake record indicates a large destructive earthquake occurred around this area in A.D. 1845, thus likely rupturing of the Chelungpu fault. We thus argue the prior deformation observed in the excavations may have been produced by the 1845 earthquake, an event that occurred 155 years ago, consistent with the radiocarbon age constraint that suggests the mud units are less than 200 years old.

The displacement of the penultimate event on the Chelungpu fault can be roughly estimated based on the observation on the excavation profiles. An old anticlinal warp beneath the broad crest of the 1999 event shows three previous scarps buried by younger deposits (Fig. 4). Two westfacing scarps associated with two east-dipping thrust faults reveal an apparent vertical offset of about 0.3 and $0.5 \mathrm{~m}$. Correction for fault dip of $30^{\circ}-40^{\circ}$ yields reverse slips of about 0.5 and $0.9 \mathrm{~m}$, respectively. An east-facing scarp associated with the west-dipping backthrust to the east of the anticlinal warp displays slip on a backthrust of about $1 \mathrm{~m}$. 

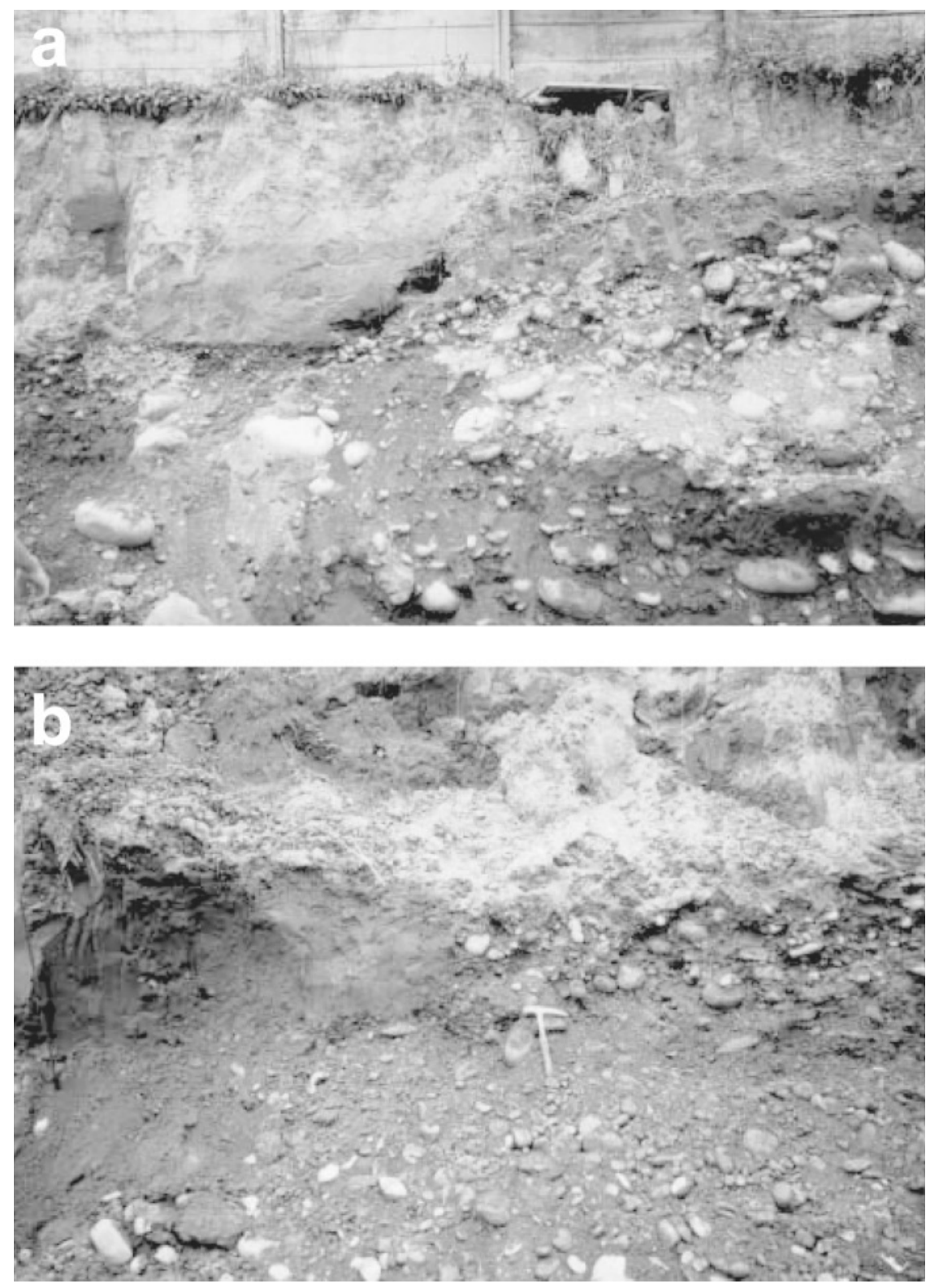

Figure 9. Photographs of the buried scarps in the middle portion of the principal excavated profile (T1). Upper photograph shows the two successive buried scarps that that offset the top of the gravel deposits. Lower photograph illustrates one of the scarps in detail. Colluvial deposits observed downslope of the scarps were interpreted as evidence for a prior event.

Excluding the problematic pre-existing scarp on the 1999 principal rupture fault, which likely indicates less than 0.5 $\mathrm{m}$ of vertical offset, we obtain a total slip of about $2.4 \mathrm{~m}$ for the prior event. Consequently, it seems that the penultimate event (1845 earthquake?) was smaller in magnitude with respect to the 1999 one. It is worthy to note that the prior event did not accommodate displacement similar to that produced in 1999; it had less displacement on the primary thrust and more on the backthrust, plus a broad intervening anticline. We argue this illustrates the problem of using displacements measured at single excavation sites to estimate the magni- tude of past events because slip may be partitioned between a primary thrust and a backthrust differently for subsequent events. Further paleoseismic investigations are thus required for better understanding of the late Quaternary behavior of the Chelungpu thrust and its role in accommodating shortening in the Taiwan orogen.

\section{Long-Term Slip Rate on the Chelungpu Fault}

We also attempt to constrain the long-term slip rate of the Chelungpu fault based on previously published retro- 


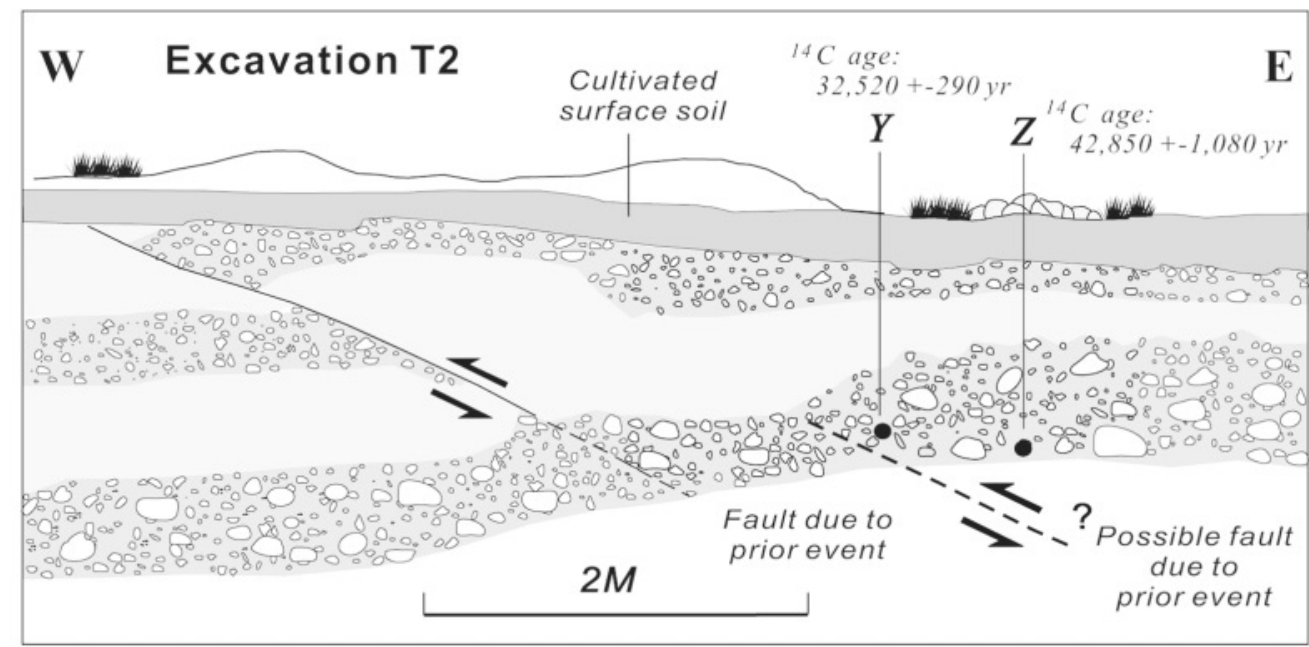

Figure 10. Sketch of buried thrust scarps in the smaller excavation (T2), $40 \mathrm{~m}$ to the south and parallel to the principal profile. The buried thrust, capped by a humancultivated soil, offsets the gravel layer $50 \mathrm{~cm}$. Two wood samples in the gravels yielded radiocarbon ages of ca. 32 and $42 \mathrm{ka}$. The ages are interpreted to indicate reworking of the samples (the actual age of the deposit is younger), based on the lack of soils developed in the deposit.

deformable cross sections (Suppe, 1987; Angelier et al., 2000). The total dip-slip offset along the Chelungpu fault is estimated as about 10 to $15 \mathrm{~km}$. There is no severe temporal constraint for the onset of shortening across the fault. However, a regional change in depositional environment from shallow marine to terrestrial alluvial and floodplains occurs at about $1 \mathrm{Ma}$ in the central foothills of western Taiwan (Chi and Huang, 1981; Chang and Chi, 1983). This widespread facies change is interpreted to correspond to the onset of uplift in the Taiwan foothill belt and the Central Range during Pliocene-Pleistocene mountain building of Taiwan (Teng, 1990). We tentatively assign an age of $1 \mathrm{Ma}$ for the onset of the Chelungpu faulting, as this represents the beginning of substantial uplift in the hanging wall of the fault. The long-term slip rate is thus $10-15 \mathrm{~mm} / \mathrm{yr}$. If this longterm slip rate is divided into $4 \mathrm{~m}$ of slip at the Wufeng site, an average recurrence interval of earthquakes along the Chelungpu fault is $267-400$ years.

The GPS measurements of the past decade indicate a horizontal shortening rate of about $80 \mathrm{~mm} / \mathrm{yr}$ across the whole island (Yu et al., 1997, 1999). About 30-40 mm/yr of shortening occurs in eastern Taiwan within the plateboundary suture of the Longitudinal Valley and the Coastal Range of the Luzon arc system, thus $40-50 \mathrm{~mm} / \mathrm{yr}$ of horizontal shortening must be distributed across the fold-andthrust belt of western Taiwan. Two pairs of GPS stations across the Chelungpu fault suggest $7-10 \mathrm{~mm} / \mathrm{yr}$ of shortening across the fault. This short-term GPS rate is not only significantly lower than the total horizontal shortening of $40-50 \mathrm{~mm} / \mathrm{yr}$ across the foothills, but also lower than the long-term rate of $10-15 \mathrm{~mm} / \mathrm{yr}$ across the Chelungpu fault.

\section{Conclusions}

The 1999 surface rupture of the reactivated Chelungpu thrust in western Taiwan provides an unusual opportunity to map surface displacement along an active range-front thrust fault, to characterize complex structures produced by a large earthquake, and to investigate its intimate relationship to scarps produced during earlier ruptures. We mapped and analyzed two exposures in two excavations, including a 3- to 5-m-deep, 70-m-long vertical exposure and a lesser 3m-deep, 10-m-long exposure across the 1999 rupture near Wufeng, southeast of Taichung city.

The excavations reveal a 60 -m-wide zone of surface deformation within fine-grained overbank deposits and soils and underlying fluvial cobbly gravel beds. Surface deformation from the 1999 event at the site is characterized by a broad anticline with an abrupt west-facing 2.5-m-high scarp (i.e., the principal rupture) to the west and a lesser eastfacing scarp to the east. Analysis of the principal surface rupture illustrates the complexity of scarp development, including initial failure on the basal, east-dipping thrust, followed by a breakthrough wedge thrust and a pop-up of an overlying symmetric anticlinal fold between two opposing secondary thrust faults.

Quantitative analysis of the main thrust scarp based on a simple line-length measurement along four horizons of the sedimentary contacts suggests average horizontal shortening of $3.3 \pm 0.3 \mathrm{~m}$ in the 1999 event at Wufeng. The net vertical offset is $2.2 \pm 0.1 \mathrm{~m}$ across the principal rupture. These values yield a total slip of $4.0 \pm 0.2 \mathrm{~m}$ and an estimate of $34^{\circ}$ for the dip of the principal fault plane below the excavation. 
Evidence of prior rupture was apparent in the excavation. First, different lithofacies on opposite sides of the principal 1999 rupture zone suggest a possible prior rupture across this fault trace. The location of the facies contact is coincident with the 1999 fault trace, suggesting the sediments were deposited in association with pre-existing fault scarp. Second, a buried anticlinal warp associated with three buried thrust faults beneath the broad anticlinal crest of the 1999 event exhibit clear evidence of prior deformation. Deformation of older strata indicates the prior event occurred after the cobbly gravels had been deposited and before deposition of the overbank sands. Radiocarbon dating shows a depositional hiatus exists between the $<200$-yr overbank sand and the much older fluvial gravels. We argue prior events correspond to historical accounts of shaking in A.D. 1845.

Based on previously published cross sections, a longterm slip rate of $10-15 \mathrm{~mm} / \mathrm{yr}$ is estimated for the Chelungpu fault for the past $1 \mathrm{~m} . \mathrm{y}$. This rate is significantly higher, however, than geodetic rates of shortening across the Chelungpu fault that suggest $7-10 \mathrm{~mm} / \mathrm{yr}$ of shortening across the fault. Given $4 \mathrm{~m}$ of average slip and a long-term slip rate of $10-15 \mathrm{~mm} / \mathrm{yr}$, the average recurrence interval for the Chelungpu thrust is between 267 and 400 years.

\section{Acknowledgments}

This study was supported by Institute of Earth Sciences, Academia Sinica, National Taiwan University, Central Geological Survey, and National Science Council Grants NSC88-2116-M001-037 and NSC89-2116M001-037. Helpful reviews and comments by P. Knuepfer and an anonymous reviewer greatly improved the manuscript. This is a contribution of the Institute of Earth Sciences, Academia Sinica, IESEP2001-013, and of Caltech's Seismological Laboratory 8829.

\section{References}

Angelier, J., H. T. Chu, J. C. Lee, J. C. Hu, F. Mouthereau, C. Y. Lu, B. Deffontaines, S. Lallemand, Y. B. Tsai, J. D. Chow, and D. Bureau (2000). Geological knowledge and seismic risk mitigation: insights from the Chi-Chi earthquake, Taiwan, in Proceedings of International Workshop on Annual Commemoration of Chi-Chi Earthquake, C. H. Loh, and W. I. Liao, (Editors), National Center for Research on Earthquake Engineering, Taipei, Taiwan, Vol. 1, 13-24.

Central Geological Survey. (1999a). Map of surface ruptures along the Chelungpu fault during the Chi-Chi earthquake, Taiwan, Central Geological Survey, MOEA, Taipei, Taiwan, scale 1:25,000.

Central Geological Survey. (1999b). Report of the geological survey of the 1999 Chi-Chi earthquake (in Chinese), Central Geological Survey, Taipei, Taiwan.

Chang, S. S. L., and W. R. Chi (1983). Neogene nannoplankton biostratigraphy in Taiwan and the tectonic implications, Petrol. Geol. Taiwan 19, 93-147.

Chen, Y. G., W. S. Chen, J. C. Lee, Y. H. Lee, C. T. Lee, H. C. Chang, and C. H. Lo (2001). Surface rupture of 1999 Chi-Chi earthquake yields insights on active tectonics of central Taiwan, Bull. Seism. Soc. Am. 91, no. 5, 977-985.

Chi, W. R. and H. M. Huang (1981). Nannobiostratigraphy and paleoenvironments of the Late Neogene sediments and their tectonics implications in Miaoli, Taiwan, Petrol. Geol. Taiwan 18, 111-130.
Chinese Petroleum Corporation (1974). Geological map of Miaoli, scale $1: 100,000$.

Chinese Petroleum Corporation (1982). Geological map of Taichung, scale $1: 100,000$.

Chou, J. T. (1971). A sedimentologic and paleogeographic study of the Neogene formations in the Taichung region, Western Taiwan, Petrol. Geol. Taiwan 9, 43-66.

Chung, J. K., and T. C. Shin (1999). Implication of the rupture process from the displacement distribution of strong ground motions recorded during the 21 September 1999 Chi-Chi, Taiwan earthquake, TAO 10, no. 4, 777-786.

Institute for Earthquake Sciences (1999). The Chi-Chi Earthquake in Taiwan, http://www.earth.sinica.edu.tw/921/921 chichi_main_eng.htm.

Kao, H., and W.-P. Chen (2000). The Chi-Chi earthquake sequence: active out-of-sequence thrust faulting in Taiwan, Science 288, 2346-2349.

Kikuchi, M., Y. Yagi, and Y. Yamanaka (2000). Source process of the ChiChi, Taiwan, earthquake of September 21, 1999 inferred from teleseismic body waves, Part. 1, Bull. Earthquake Res. Inst. Univ. Tokyo $\mathbf{7 5}, 1-14$.

Lee, J. C., H. T. Chu, J. Angelier, Y. C. Chan, J. C. Hu, C. Y. Lu, and R. J. Rau (2001). Structural characteristics of northern surface ruptures of the $1999 \mathrm{Mw}=7.6$ Chi-Chi, Taiwan Earthquake, J. Struct. Geol. (in press).

Ma, K. F., C. T. Lee, Y. B. Tsai, T. C. Shin, and J. Mori (1999). The ChiChi, Taiwan earthquake: large surface displacements on an inland thrust fault, EOS 80, no. 50, 605-611.

Ma, K.-F., T.-R. Song, S.-J. Lee Song, H.-I. Wu. (2000). Spatial slip distribution of the September 20, 1999, Chi-Chi, Taiwan, earthquake (Mw7.6): inverted from teleseismic data, Geophys. Res. Lett. 27, 3417-3420.

Mouthereau, F. (2000). Evolution structurale et cinematique recente à actuelle de l'avant-pays plisse d'une chaine de collision oblique: Taiwan, Mem. Sc. Terre Thesis, Univ. P.-et-M. Curie.

Mouthereau, F., B. Deffontaines, O. Lacombe, and J. Angelier (2001). Along-strike variations of the Taiwan belt front: basement control on structural style, wedge geometry, and kinematics, Geol. Soc. Am. Spec. Pub. (in press).

Philip, H., and M. Meghraoui (1983). Structural analysis and interpretation of the surface deformations of the El Asnam earthquake of October 10, 1980, Tectonics 2, no. 1, 17-49.

Philip, H., E. Rogozhin, A. Cisternas, J. C. Bousquet, B. Borisov, and A. Karakhanian (1992). The Armenian earthquake of 1998 December 7: faulting and folding, neotectonics and paleoseismicity, Geophys. J. Int. 110, 141-158.

Suppe, J. (1983). Geometry and kinematics of fault-bend folding, Am. J. Sci. 283, 684-721.

Suppe, J. (1987). The active Taiwan mountain belt, in Anatomy of Mountain Chains, J. P. Schaer and J. Rogers, (Editors), Princeton University Press, 277-293.

Teng, L. S. (1990). Geotectonic evolution of late Cenozoic arc-continent collision in Taiwan, Tectonophysics 183, 57-77.

Yu, S. B., H. Y. Chen, and L. C. Kuo (1997). Velocity field of GPS stations in the Taiwan area, Tectonophysics 274, 41-59.

Yu, S. B., L. C. Kuo, R. S. Punongbayan, and E. G. Ramos (1999). GPS observation of crustal deformation in the Taiwan-Luzon region, Geophys. Res. Lett. 26, 923-926.

Yu, S. B., L.-C. Kuo, Y.-J. Hsu, H.-H. Su, C.-C. Liu, C.-S. Hou, J.-F. Lee, and T.-C. Lai, C.-L. Liu, T.-F. Tseng, C.-S. Tsai, and T.-C. Shin (2001). Preseismic deformation and coseismic displacements associated with the 1999 Chi-Chi, Taiwan, earthquake, Bull. Seism. Soc. Am. 91, no. 5, 995-1012.

Institute of Earth Sciences Academia Sinica

P.O. Box 1-55

Nankang, Taipei, Taiwan, R.O.C.

(J.-C.L., Y.-C.C.) 
Department of Geology

National Taiwan University

Taipei, Taiwan, R.O.C.

(Y.-G.C., W.-S.C.)

Seismological Laboratory

Division of Geological and Planetary Science

$100-23$

Caltech

Pasadena, California

(K.S.)

Department of Geology

University of Colorado

Boulder, Colorado

(K.M.)
Central Geological Survey

P.O. Box 968

Taipei, Taiwan, R.O.C. (H.-T.C.)

Department of Geology

Central Washington University

Ellensberg, Washington

(C.R.)

Department of Geosciences

Oregon State University

Corvallis, Oregon

(R.Y.) 